\title{
Environmental policy integration and the architecture of global environmental governance
}

\author{
Frank Biermann · Olwen Davies · Nicolien van der Grijp
}

Accepted: 16 May 2009/Published online: 14 August 2009

(C) The Author(s) 2009. This article is published with open access at Springerlink.com

\begin{abstract}
This article discusses environmental policy integration-a concept so far mainly applied to domestic and European politics-at the global level. The article distinguishes between integration of institutions, of organizations, and of their bureaucracies, and it addresses both internal integration (within the environmental policy domain) and external integration (between environmental policies and non-environmental policies). The overall focus is on one set of policy reform proposals that have been salient in the global environmental governance debate for the last decades: the question of whether the creation of a world environment organization would improve the effectiveness, legitimacy, and efficiency of global environmental governance. We revisit this debate and explore the options for organizational change, including clustering, upgrading, streamlining, and hierarchical steering, with a focus on whether the reform proposals can bring about environmental policy integration. We conclude that in the longer term, upgrading of the UN Environment Programme to a UN specialized agency, with additional and increasing streamlining of other institutions and bureaucracies, offers the most potential for environmental policy integration and does not appear to be unrealistic.
\end{abstract}

Keywords Global environmental governance · United Nations ·

World environment organisation · Environmental policy integration ·

International organizations

$\begin{array}{ll}\text { Abbreviations } \\ \text { CSD } & \text { Commission on Sustainable Development } \\ \text { FAO } & \text { United Nations Food and Agriculture Organization } \\ \text { ILO } & \text { International Labour Organization } \\ \text { IMO } & \text { International Maritime Organization } \\ \text { MARPOL } & \text { International Convention for the Prevention of Pollution from Ships } \\ \text { UN } & \text { United Nations }\end{array}$

F. Biermann $(\bowtie) \cdot$ O. Davies · N. van der Grijp Institute for Environmental Studies, VU University Amsterdam, De Boelelaan 1087, 1091 HV Amsterdam, The Netherlands

e-mail: frank.biermann@ivm.vu.nl 
UNDP United Nations Development Programme

UNEO United Nations Environment Organization

UNEP United Nations Environment Programme

WHO World Health Organization

WTO World Trade Organization

\section{Introduction}

It is a frequent argument in writings on global environmental governance that the institutions and organizations active in this field are not living up to the challenges (overview in Elliott 2005; Biermann and Pattberg 2008; Kanie and Haas 2004). This finding-even though not shared by all observers - has led to a policy debate on the reform of the entire architecture $^{1}$ of institutions and organizations. In 1972, governments created the United Nations Environment Programme (UNEP) as catalyst and coordinator of environmental policy in the United Nations (UN) system, and-even though the term was then not usedas a protagonist of environmental policy integration. However, today many argue that UNEP is not equipped to adequately deal with pressing environmental problems, partially because its status of a programme brings limitations in the area of funding, staffing, status, and mandate (Biermann 2005; Ivanova 2007a, 44; Bauer 2009). In addition, there is widespread dissatisfaction with the current fragmentation of global environmental governance and the lack of coordination that leads to gaps, overlaps, and inconsistencies among organizations and programmes (Andresen 2007, 330). There are hundreds of treaties and agencies operating with little formal linkages with each other. Norms and standards are created independently, and most specialized agencies and bodies have initiated their own environmental programmes independently from each other and with little effective policy coordination among themselves or with UNEP.

In response to this perceived failure of global environmental governance, several voices have called for the establishment of a new strong agency that would replace, or upgrade, UNEP (see Bauer and Biermann 2005; Biermann and Bauer 2005 on details of the reform debate). Such proposals come under a variety of titles that sometimes-yet not alwaysreflect different priorities or functions that such a new agency could have, such as World Environment Organization, United Nations Environment Organization, Global Environment Organization, World Organization for Environment and Development, World Organization on Sustainable Development or United Nations Organization for Environmental Protection. One argument for a radically different approach is that it may enhance the potential for environmental policy integration within the environmental policy domain as well as in other policy areas. Yet other scholars prefer to stay closer to the current system and to reform it in a way that strengthens environmental policy without creating a new agency that may be costly in both financial and political terms (Oberthür and Gehring 2005).

This article revisits the debate on the architecture of global environmental governance and links it to discussions about environmental policy integration. It aims to bring the debate further by examining several organizational and institutional options in relation to their potential to achieve environmental policy integration, and is in this respect complementary to the article of Oberthür (2009) in this issue.

\footnotetext{
${ }^{1}$ See Biermann et al. (2009a) on a conceptualization of "global governance architectures".
} 
The structure of the article is as follows. Section 2 elaborates how the concept of environmental policy integration can be applied to global environmental governance. Section 3 revisits and summarizes the debate on the architecture of global environmental governance. The main Sect. 4 then explores the options for organizational and institutional change, including clustering, upgrading, streamlining, and hierarchical steering, and examines the different options in relation to their potential for environmental policy integration. Section 5 concludes.

\section{Conceptualizing environmental policy integration at the global level}

Environmental policy integration became a leading concept in global environmental governance with the publication of the Brundtland report in 1987 (World Commission on Environment and Development 1987; see also Nilsson et al. 2009), drawing on comparable discourses in national policy making (Nilsson 2005; Hertin and Berkhout 2003; Lafferty and Hovden 2003; Nilsson and Eckerberg 2007). The Brundtland report defined sustainable development as including environmental, economic, and social dimensions. Importantly, it has been argued that the critical importance of the concept of sustainable development is that it is an integrationist principle (McGoldrick 1996, 818). In the words of the international lawyer Fitzmaurice (2001, 47), "Very broadly, sustainable development can be defined as a concept, which attempts to integrate environmental considerations into economic and other development and which takes into account other than environmental needs while formulating the principles of environmental protection".

The integration of environmental protection was formally recognized as a principle of international law in 1992, when the Rio Declaration on Environment and Development gave it a legal status. ${ }^{2}$ More precisely, Principle 4 of the Declaration states that "[i]n order to achieve sustainable development, environmental protection shall constitute an integral part of the development process and cannot be considered in isolation from it". The International Law Association has taken the development of the integration principle further. ${ }^{3}$ In its New Delhi Declaration of Principles of International Law relating to Sustainable Development, the principle is incorporated as the principle of integration and interrelationship. The Declaration states in paragraphs 7.1-7.3 that the "principle of integration reflects the interdependence of social, economic, financial, environmental, and human rights aspects of principles and rules of international law relating to sustainable development as well as of the interdependence of the needs of current and future generations of humankind" and that "All levels of governance-global, regional, national, subnational, and local—and all sectors of society should implement the integration principle, which is essential to the achievement of sustainable development". In addition, "states should strive to resolve apparent conflicts between competing economic, financial, social, and environmental considerations, whether through existing institutions or through the establishment of appropriate new institutions".

\footnotetext{
${ }^{2}$ Rio Declaration on Environment and Development, A/CONF.151/26 (Vol. I).

${ }^{3}$ Resolution 3/2002 of the International Law Association: The New Delhi Declaration of Principles of International Law Relating to Sustainable Development, published in UN Doc A/57/329. The ILA New Delhi Declaration includes a focus on: (1) Duty to ensure sustainable use of natural resources, (2) Equity and the eradication of poverty, (3) Common but differentiated responsibilities, (4) Precautionary approach to human health, natural resources, and ecosystems, (5) Public participation and access to information and justice, (6) Good governance, and (7) Integration and interrelationship, in particular in relation to human rights and social, economic, and environmental objectives.
} 
In order to make this principle operational at the policy level, the EPIGOV project defines environmental policy integration in a restricted sense, namely, as the integration of environmental concerns into other policy areas (Von Homeyer et al. 2009; Nilsson et al. 2009). Such areas may include, for example, economic and social development, agriculture, trade, energy, infrastructure, and transport. Hence, the EPIGOV definition focuses on external policy integration, denoting integration beyond the environmental policy domain and excluding internal integration within the environmental policy domain. Yet this approach, while sensible at the national and European level, meets problems at the global level, where institutional and organizational fragmentation within the environmental domain is seen as one of the main problems. Thus, our subsequent analysis will also need to include this dimension of internal integration.

Consequently, we propose to organize research, appraisal, and policy reform debates on environmental policy integration at the global level around four analytical questions, which follow from a focus on two different dimensions of the debate: institutional and organizational integration, and internal and external integration. This is also the basic structure of the present analysis.

(1) Institutions, Organizations, and Bureaucracies. First, it is important to distinguish between the organizational and the institutional dimensions of governance. Institutions are systems of norms, rules, and decision-making procedures that give rise to social practices, that assign roles to participants in these practices, and that guide interactions among participants (IHDP 1999; Young et al. 2008; also Simmons and Martin 2002, 192-4). Organizations, on the other hand, are commonly defined as actors that have physical qualities, such as staff, headquarters, resources, and formalized leadership, and that effectively pursue a policy. The concept of organizations can apply to all kinds of entities, scales, and objectives and may range from public to private and from global to local. In this article, we focus on intergovernmental organizations that have been set up by governments to pursue a public policy.

Furthermore, the broader notion of intergovernmental organizations needs to be distinguished from the bureaucracy that stands at the center of the organization. We define intergovernmental organizations as the complex of three elements: (a) a normative framework of principles and rules governing the organization; (b) state members of the organizations; and (c) a bureaucracy and its leader at the center of the organization (see Biermann et al. 2009b in more detail on this distinction). Thus, it is important in the reform debate to distinguish between intergovernmental institutions (often also known as "regimes"), ${ }^{4}$ intergovernmental organizations, and intergovernmental bureaucracies. To give one illustration: the 1973 International Convention for the Prevention of Pollution from Ships (MARPOL) is an effective framework of principles, norms, rules, and decisionmaking procedures around this issue area. The International Maritime Organization (IMO) is, as an organization, the collective actor of the IMO member states to support the MARPOL convention, for example through agreement on more specific rules and implementation standards. The IMO Secretariat is then the intergovernmental bureaucracy that is mandated to serve the parties of both IMO and MARPOL in their activities, to prepare new

\footnotetext{
4 The term "international regimes" more specifically denotes-in Krasner's $(1983,2)$ standard definition"sets of implicit or explicit principles, norms, rules, and decision-making procedures around which actors' expectations converge in a given area of international relations". However, in order to stay within the general terminology of the social sciences, we use in this article, throughout, the term international institutions rather than regimes.
} 
policies, and to help implementing the intergovernmental institutional framework (see Campe 2009 for a case study on the IMO secretariat based on this framework).

The influence of intergovernmental organizations and their bureaucracies in world politics has been at the center of an extensive debate in recent years. Different organizations and bureaucracies have been shown to have different degrees of influence, and the influence varies in different functional areas. In line with recent research (Biermann and Siebenhüner 2009), we propose to distinguish three dimensions of the influence of intergovernmental bureaucracies: cognitive, normative, and executive influence.

The cognitive influence denotes the role that intergovernmental bureaucracies play in fostering the informational basis of (environmental) policy making, for example through the initiation, generation, synthesis, and dissemination of scientific knowledge on environmental problems, through the provision of institutional knowledge to negotiators, or through the raising of awareness and the advancement of specific (pro-environmental) discourses in national and international debates. The normative influence refers to the role that (some) intergovernmental bureaucracies play in fostering the progressive development of international and national norms, for example through the initiation of intergovernmental norm-setting processes, the proactive support of on-going negotiations, or the support and guidance of national and subnational norm setting. The executive influence denotes the important role that many international bureaucracies have in supporting policy making and policy implementation on the ground, for example through funding, designing, supporting or implementing (environmental) projects in certain countries. Recent research on the influence of intergovernmental environmental bureaucracies has shown that many bureaucracies have some autonomous influence on all of these three dimensions, with some bureaucracies even having had decisive influence in certain phases of the policy cycle (see the case studies in Biermann and Siebenhüner 2009).

(2) External and Internal Integration. Second, one needs to distinguish whether environmental policy integration is sought within the environmental realm (internal integration) or between environmental policy and other policy domains (external integration). Naturally, boundaries are blurred, and some policies may be seen as having environmental as well as non-environmental elements. The protection of the global climate through reducing emissions of greenhouse gases, for example, can be seen as an objective of environmental policy (probably the most common frame in the North), but also as a core issue of economic development policy (a frame often advanced in the South). Other examples are the Rotterdam and Stockholm conventions on hazardous substances that aim at integrating both environmental and health concerns into industrial and agricultural policies.

Systematizing the debate on a new UN agency on environmental issues according to these two basic differentiations, we arrive at the following matrix of analytical questions (see Table 1).

Analyzing the recent proposals for a new UN agency in and around the field of environmental policy, it is thus important to specify what kind of question the proposal addresses. In many cases, most proposals implicitly address more than one of the aspects outlined above.

\section{Taking stock: revisiting the debate on global environmental governance}

The debate on strengthening global environmental governance and the possible role of a new intergovernmental agency in this field dates back more than three decades. Bauer and 
Table 1 Analytical questions

\begin{tabular}{|c|c|c|}
\hline & Institutional reform & Organizational reform \\
\hline $\begin{array}{l}\text { Internal } \\
\text { policy } \\
\text { integration }\end{array}$ & $\begin{array}{l}\text { Will a new agency improve the integration } \\
\text { of different intergovernmental } \\
\text { environmental institutions? }\end{array}$ & $\begin{array}{l}\text { Will a new agency improve the cognitive, } \\
\text { normative, and executive influence of the } \\
\text { UN system by better integrating existing } \\
\text { actors with an environmental mandate? }\end{array}$ \\
\hline $\begin{array}{l}\text { External } \\
\text { policy } \\
\text { integration }\end{array}$ & $\begin{array}{l}\text { Will a new agency improve the integration } \\
\text { of intergovernmental environmental } \\
\text { institutions with non-environmental } \\
\text { institutions? }\end{array}$ & $\begin{array}{l}\text { Will a new agency improve the cognitive, } \\
\text { normative, and executive influence of the } \\
\text { UN system by better integrating } \\
\text { environmental actors and non-environmental } \\
\text { actors? }\end{array}$ \\
\hline
\end{tabular}

Biermann (2005) offer a review of the literature, in which they distinguish three peaks in the debate: An initial phase in the early 1970s, around the 1972 UN Conference on the Human Environment; a second peak in the mid-1990s, following the 1992 UN Conference on Environment and Development; and a third peak in the context of the 2002 World Summit on Sustainable Development. The French initiative for a new agency from 2007, centered on the Paris Call for Action of February 3 2007, has triggered what one could describe as a fourth peak, followed by new initiatives such as Brazil's proposal for a combined organization for environment and development. This section summarizes these four peaks of proposals on a new intergovernmental environmental organization, with an emphasis on the most recent developments.

The first proposals to create a global organization for environmental politics date back to the early 1970s and resulted in the creation of the United Nations Environment Programme (UNEP), following a decision adopted at the 1972 Stockholm Conference on the Human Environment (United Nations General Assembly 1972). UNEP was set up as a subsidiary body of the UN General Assembly, reporting through the UN Economic and Social Council. Originally, governments wanted UNEP to evolve into an "environmental conscience" within the UN system that would act as a catalyst triggering environmental projects in other bodies and help to coordinate UN environmental policies. In practice, however, UNEP has not fully met its promise and has been forced to lower its ambitions over time. Recently, it has even been characterized as weak, underfunded, overloaded, and remote (Haas 2005, 49; more positive is Bauer 2009).

The debate about a larger, more powerful agency for global environmental policy was revived in 1989. The Declaration of The Hague, initiated by the Netherlands, France, and Norway, called for an authoritative international body on the atmosphere. ${ }^{5}$ Yet at the 1992 UN Conference on Environment and Development, the main reform outcome was the creation of the UN Commission on Sustainable Development (CSD), a consultative organ of the UN Economic and Social Council with limited representation that mainly serves as forum for deliberation and debate (for example Dodds et al. 2002).

This situation triggered a second round of proposals for organized intergovernmental environmental regulation (for example Charnovitz 1993, 2005; Esty 1994; Runge 1994). The revival of the debate was especially fuelled by continuing doubts regarding the effectiveness of UNEP and limited competences of the (then new) UN Commission on Sustainable Development. A 1997 report by an UN office heaped heavy criticism on the

\footnotetext{
5 Declaration of The Hague, March 11, 1989, concerning the earth's atmosphere and possible approaches to preserve its quality.
} 
management and the overall performance of UNEP (United Nations Office of Internal Oversight Services 1997). The report argued that UNEP lacked a clear role and that it was not clear to staff or stakeholders what that role should be. At the 1997 Special Session of the UN General Assembly on environment and development, Brazil, Germany, Singapore, and South Africa submitted a joint proposal for a world environment organization to replace UNEP. ${ }^{6}$ In reaction, Secretary General Kofi Annan called on the UN General Assembly to set up a task force, led by then UNEP Executive Director Klaus Töpfer, to assess the environmental activities of the UN (United Nations Secretary-General 1998). Following the report of this task force, an Environmental Management Group was created within the UN system, and it was decided that the UNEP Governing Council should meet regularly at ministerial level.

These initiatives stimulated further academic input in the discourse, amounting to a third peak in attention around the 2002 World Summit on Sustainable Development. The broadening of the debate resulted in a variety of new views about what a world environment organization should or should not do. Biermann (2000, 2001, 2002) developed detailed proposals that outlined a possible upgrade of UNEP to a World Environment Organization. Bharat Desai (2000) examined prospects for a UN Environment Protection Organization that would report to a newly mandated UN Trusteeship Council. Tarasofsky (2002) discussed how UNEP and its Global Ministerial Environment Forum could be substantially strengthened without changing the programme's legal status or name. Haas (2004) argued for a Global Environmental Organization that would mainly serve to centralize the collection and dissemination of environmental expertise. Kimball (2002) discussed the international institutional conditions under which UNEP might be transformed into a global environmental organization. Others added an economic perspective to a debate that had thus far been sustained by diplomats, international lawyers, and political scientists (Whalley and Zissimos 2002). From the political community, for instance Gustave Speth, former head of UNDP, also supported the creation of a new environmental organization (Speth 2004). Klaus Töpfer, when still executive director of UNEP, emphasized the nexus of developmental and environmental concerns and was thus reluctant to call for a specialized agency that would focus exclusively on the environment. Instead, Töpfer appeared to support the creation of a strong World Organization on Sustainable Development. $^{7}$

Most recently, the debate has been given new impetus by the diplomatic effort of France to create a UN Environment Organization. ${ }^{8}$ In 2003, the French government circulated a proposal to transform UNEP into an "Organisation spécialisée des Nations Unies pour l'environnement", which follows up on earlier French initiatives to replace UNEP by an "Organisation mondiale de l'environnement" or an "impartial and indisputable global center for the evaluation of our environment". " This proposal has been emphasized by the 2007 Paris Call for Action during the Citizens of the Earth Conference for Global

\footnotetext{
${ }^{6}$ UN document A/S-19/23, June 24, 1997.

7 See for instance Töpfer's presentation in the Global Governance Speakers Series on February 28, 2003, Berlin, Germany [on file with authors].

${ }^{8}$ Proposition française de transformer le Programme des Nations Unies pour l'environnement en une Organisation spécialisée des Nations Unies pour l'environnement, Septembre 12, 2003 [on file with authors].

9 See the speech by the French minister for ecology and sustainable development, Roselyne BachelotNarquin, who reaffirmed the commitment of the French government to strive for the creation of a UNEO together with like-minded countries (Bachelot-Narquin 2004).
} 
Ecological Governance. ${ }^{10}$ The Call for Action pleas for the adoption of a Universal Declaration of Environmental Rights and Duties, which would ensure a new human right to a sound and well-preserved environment. The aim to transform UNEP into a UN Environment Organization remains a strong focal point, highlighted by the establishment of a Group of Friends of the UN Environment Organization. Subsequently, the group has met in Morocco for in-depth discussions on mandates and institutional aspects involved in the establishment of such an organization.

The French initiative has been supported by a consultative process within the UN system itself. In 2005, the Permanent Representatives of Mexico and Switzerland were assigned as co-chairs to the Informal Consultative Process on the Institutional Framework for the United Nations' Environmental Activities (Berruga and Maurer 2007). This process aimed at exploring the possibility of a more coherent institutional framework to address the need for more efficient environmental activities in the UN system. ${ }^{11}$ After a series of consultations with country delegations, members of the UN Secretariat and secretariats of multilateral environmental agreements, as well as with scientists, business leaders, and non-governmental organizations, the co-chairs presented several proposals on how to address the shortcomings in international environmental governance (Co-Chairs Options Paper 2007). Among these proposals was the establishment of a UN Environment Organization. In a first reaction to this Co-Chairs Options Paper, the European Union collectively supported the formation of a UN Environment Organization. ${ }^{12}$

Developing country positions varied in this debate. Developing countries initially feared that environmental governance could be a threat to economic development (Persson 2009). The influential Founex Report of 1971, for example, argued that the environmental problems of developing countries are "predominantly problems that reflect the poverty and very lack of development of their societies. [...] It is evident that, in large measure, the kind of environmental problems that are of importance in developing countries are those that can be overcome by the process of development itself. [...] In [the context of developing countries], development becomes essentially a cure for their major environmental problems" (Founex Report 1971, 4).

Among other things, the location of UNEP headquarters in Nairobi has greatly increased the support from developing countries (Najam 2005a, 309). Yet choosing this location for UNEP's headquarters has also been mentioned by some observers as a source of the problems facing UNEP, because it contributes to the fragmentation of environmental governance and makes it difficult for UNEP to attract and hold on to qualified staff (Hierlmeier 2002, 786). Importantly, however, the position of developing countries gradually evolved from opposition to participation and then to active engagement in discussions about environmental governance, which is demonstrated by their increased involvement in proposals for reform (Najam 2005a).

In sum, the debate on the architecture of global environmental governance has been through different stages in the past 30 years. An important part of the discourse has remained the question of the advantages or disadvantages of a new specialized UN agency on environmental protection. Numerous proposals for such an organization have been made (summarized in Table 2), some of which continue to resurface during different

\footnotetext{
${ }^{10}$ Paris Call for Action, February 2, 2007. Available at: http://www.ecologie.gouv.fr/conference/ ?PARIS-CALL-FOR-ACTION.

11 UN document A/RES/60/1, October 24, 2005.

12 See EU's first reaction on the co-chair's Options Paper: Informal consultative process on the institutional framework for the UN environmental activities, 2007.
} 


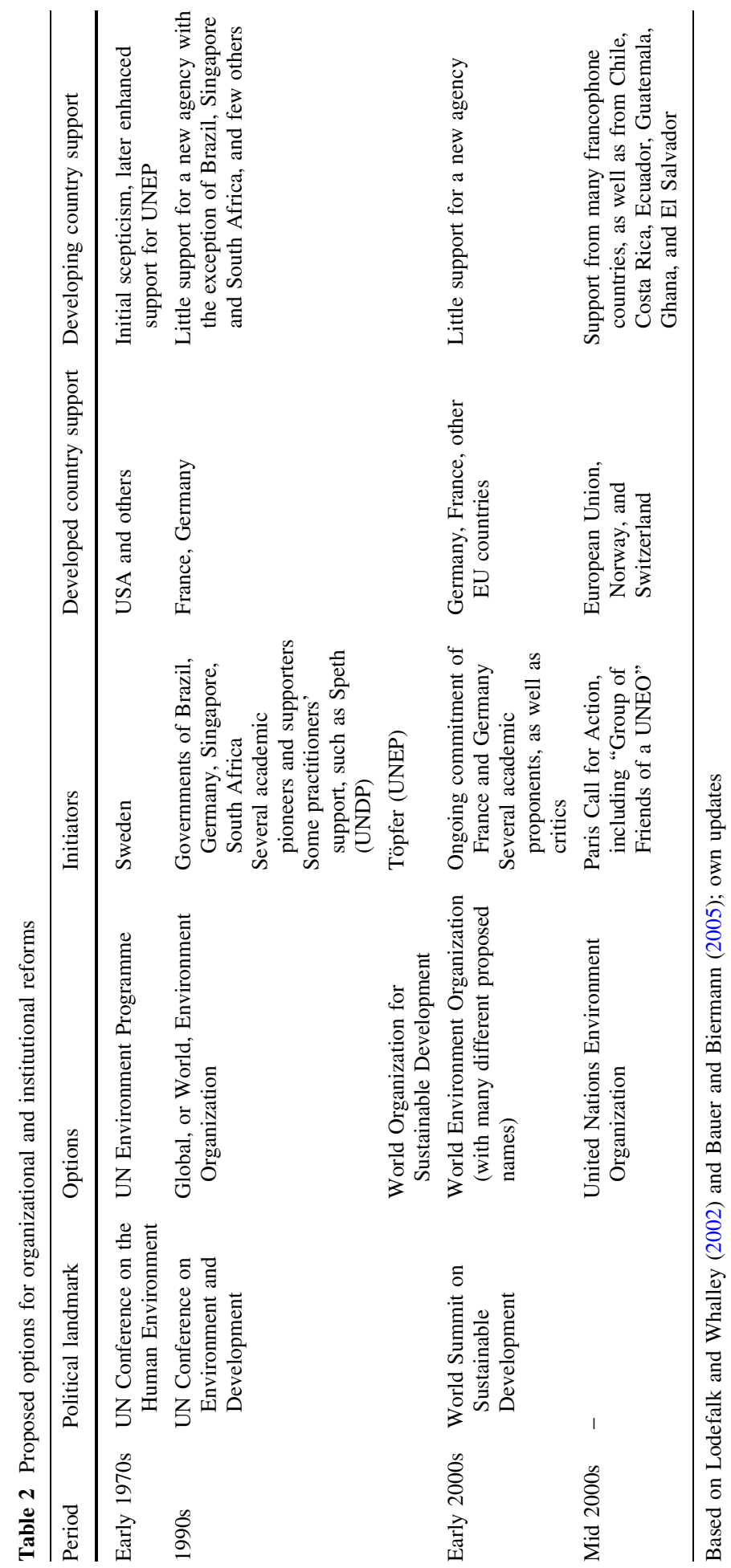


phases of the debate. Some formerly opposing voices in the academic debate have come around and now support a robust environmental pillar within the global governance system (e.g., Najam et al. 2007, which differs from Najam 2005b).

\section{Organizational options and their potential for environmental policy integration}

This section provides the first assessment of the potential for improved environmental policy integration brought about by the different reform proposals that have been advanced by governments, policy advisors, and scholars. We organize these proposals according to the classification first introduced in Biermann (2000), that is, we distinguish between proposals (a) that seek to merely upgrade UNEP to a new agency and to give it a stronger role in policy coordination and implementation; (b) proposals that seek, in addition, to integrate different organizations and institutions into a new agency ("streamlining"); and (c) proposals that seek to provide the new agency with enforcement powers that effectively limit the sovereignty of governments ("hierarchization"). Many observers have rejected the calls for the creation of a new agency, but have instead proposed other means of advancing the integration of environmental policies. These proposals-which usually target the "clustering" of existing institutions and organizations-we include in the following as well, as the least far-reaching reform strategy.

\subsection{Clustering existing institutions, organizations, and bureaucracies}

One stream of reform proposals rejects creating a new agency, but rather calls for clustering multilateral environmental agreements on a thematic or functional basis. This clustering approach is based on the assumption that the current number of international environmental institutions is too large to possibly be efficient or effective and that merging institutions and organizations (the streamlining approach discussed below) would be a troublesome task that is hardly feasible for a number of reasons (see von Moltke 2005). Instead, proposals to cluster seek to promote efficiency and effectiveness by grouping a number of institutions together without formally integrating them. The idea arose from a process of negotiations within UNEP, following Decision 21/21 of the UNEP Governing Council, aiming at reform and strengthening of international environmental management (von Moltke 2005).

In addition, the rationale for clustering is rooted in the perception that the goal of strengthening environmental governance will not be attained by the establishment of a new environmental organization in the first place. In this view, one single institution cannot adequately address the environment, as it encompasses too many different issues all with their own distinct problem structures. Instead, clustering of institutions and bureaucracies would increase the efficiency and effectiveness of existing agreements without requiring elaborate changes in legal or administrative arrangements (von Moltke 2005). Such measures could include grouping the functions of related convention secretariats together, streamlining activities and meetings, coordinating operations and budgeting, or improving transparency and participation to minimize institutional overlap and fragmentation (Ivanova 2007b).

Both from an organizational and from an institutional perspective, clustering requires the least change in comparison with the current system. With regard to organizational alterations, it would entail merely sharing functions of convention secretariats in order to 
synchronize activities. Institutional measures would be minimal too, limited for instance to the formation of a Memorandum of Understanding.

The potential for effective environmental policy integration is, therefore, rather small. First, clustering is - at least in the current proposals-restricted to internal integration within environmental policy. External integration-such as between economic and environmental institutions or organizations- has not been at the center of the clustering discourse. Second, clustering meets problems since clusters could be organized according to different principles, such as environmental medium (e.g., atmosphere), institutional functions (e.g., trade restriction), or source of pollution (e.g., long-range air pollution). Different clusters according to different mediums, functions, and sources of pollution would need to be created, possibly increasing fragmentation and inefficiencies instead of preventing them (see Biermann 2005, 137-139 in more detail). Third, since clustering will provide only for rather weak linkages between institutions and bureaucracies, a strong coordinating actor would still be needed.

In other words, a main task of coordinating and catalyzing these clustering processes would remain with UNEP. Indeed, in 1999, UN General Assembly Resolution 53/242 reaffirmed UNEP's role as the leading global environmental authority that sets the global environmental agenda and promotes the integration of the environmental aspects of sustainable development into the work of the UN system. ${ }^{13}$ However, practice has shown that, in its current state, UNEP is relatively powerless to influence environmental policy integration. It merely encourages decision makers in government, industry, and business to develop and adopt environmentally sound policies, strategies, practices, and technologies. Furthermore, UNEP lacks the authority to execute projects on the ground and cannot avail itself of any regular and predictable funding (Bauer 2009). This gives the programme little power and authority vis-à-vis the independent environmental agreements, their secretariats, or other organizations.

Clustering alone thus does not show much potential for improving environmental policy integration. Mere clustering cannot advance environmental policy integration by taking on leadership, as it does not entail the establishment of any body capable of executing such leadership. The policy process itself, including agenda setting, planning, execution, and evaluation, is hardly affected by clustering. Even though advocates of clustering claim it holds the promise of increasing the efficiency of the use of available resources, it is highly unlikely that this option would free significant budgetary resources in order to finance environmental policy integration (Oberthür 2002). Overall, the potential for improvement of external environmental policy integration by means of clustering is limited, since the scope of clustering only addresses multilateral environmental agreements.

\subsection{Upgrading UNEP to a specialized agency}

A second group of proposals focuses on upgrading UNEP to a specialized UN agency with full-fledged organizational status. Proponents of this approach have referred to the World Health Organization or the International Labour Organization as suitable models. According to this approach, other institutions and organizations operating in the environmental field would neither be integrated into the new agency nor otherwise disbanded. The new agency in this model is expected to improve the facilitation and coordination of norm-building and norm-implementation processes in comparison to UNEP. This strength

${ }^{13}$ UN document A/RES/53/242, August 10, 1999. 
would in particular derive from an enhanced mandate and better capabilities of the agency to build capacities in developing countries. This differs from UNEP's present "catalytic" mandate that prevents the programme from engaging in project implementation in the field. Furthermore, additional legal and political powers that could come with the status of a UN specialized agency could enable such a world environment organization to approve by qualified majority vote certain regulations. Its governing body could be a general assembly that could adopt drafts of legally binding treaties that have been negotiated by subcommittees under its auspices. Such powers could exceed those entrusted to the UNEP Governing Council, which has supported intergovernmental negotiations on a number of issues, but cannot adopt legal instruments by itself.

Upgrading UNEP to a specialized UN agency may thus have more potential for improving internal environmental policy integration. Merely upgrading UNEP to a specialized agency would not formally affect other institutions, organizations, and their bureaucracies, all of which would remain, in this model, independent. Yet it is likely that a stronger bureaucracy with an exclusively environmental mandate would better be able to support public discourses and policy making through scientific and other types of information and through the generation, neutral assessment, and wide dissemination of environmental knowledge. It could also be in a better position to stimulate new norm development, including through the formal initiation of new environmental treaties similar to the norm-building process of the International Labour Organization. Such a specialized agency would also be better equipped to take on a leading role in influencing environmental policy integration. Besides improved leadership capacities, various phases of the policy process could be influenced by the new organizational status. Elevated status would mean having more influence in agenda setting and the ability to plan and execute combined programmes, rather than depending on others. Organizational status would imply a fixed budget, which offers new prospects for planning. New agreements developed under the organization would most likely have a closer link to it, and the new treaty secretariats could be integrated from the start in the new organization, increasing the overall integration of intergovernmental environmental bureaucracies within one organization.

Concerning external environmental policy integration, a new UN specialized agency under this model would have formally no different relationship to non-environmental institutions and organizations than the current UNEP. Yet it is likely that with increased mandate and possibly with larger resources and staff, the new body would also be able to better influence non-environmental policy processes, thus fostering external environmental policy integration.

\subsection{Streamlining institutions, organizations, and bureaucracies}

A third group of proposals seeks to go further and advocates a more centralized or streamlined architecture. These authors make their case by challenging the substantive functional overlap between the multitude of institutions and organizations that have a say in international environmental policy. Consequently, streamlining advocates call for an approach that would integrate existing institutions, organizations, and their bureaucracies into one all-encompassing world environment organization. They argue that prospective gains in efficiency and better coordination of international environmental policy could outweigh the risks that often accompany streamlining. The integration of environmental institutions could loosely follow the model of the World Trade Organization, which has integrated diverse multilateral trade agreements under one umbrella. According to some 
scholars, ${ }^{14}$ this integrative effort could even include established intergovernmental organizations although historic evidence suggests that this might go far beyond the politically feasible.

Streamlining would entail more than moderate organizational consequences, as it signifies administrative, legal, and political integration of existing institutions, organizations, and their bureaucracies. Realizing such extensive integration would entail having to make major institutional alterations to the current system. Such alterations would include providing the new organization with the authority to formulate rules and implement them. However, streamlining does not include the authority to enforce these rules upon nations.

Streamlining has potential for internal environmental policy integration. First, international institutions could be integrated in the same way in which the many multilateral and plurilateral trade agreements function today under the overall institutional umbrella of the World Trade Organization. Normative, functional, or political conflicts between different multilateral environmental agreements could be reduced through a general legal and institutional framework. Many functions that lie today with separate institutions-such as reporting, financing, awareness raising, or dispute settlement-could be integrated in centralized mechanisms under the overarching new UN environmental agency. In this model, a new agency would also integrate a number of so far (largely) independent environmental bureaucracies, notably the many treaty secretariats. This would generate substantial efficiencies in administration, but more so increase synergies in the support functions of these smaller bureaucracies, all of which could better rely on expertise and experience of similar bureaucracies in other fields.

Regarding external environmental policy integration, a larger and stronger environment organization would be better able to provide headship in advancing environmental policy integration in other policy fields. It would be a more equal partner of the other major organizations and their bureaucracies. Centralizing environmental bureaucracies and institutions would also simplify planning processes within the environmental policy domain and free opportunities for combined planning with agencies in other policy domains. The status of an organization would enable execution of joint strategies, rather than depending on others for implementation. In the medium term, even the relocation of environmental policy tasks to a new world environment organization might be conceivable. Many non-environmental bureaucracies have in recent decades created environmental departments within their own premises. On the one hand, this can be described as successful sectoral policy integration. On the other hand, it can also lead to less far-reaching environmental policies if the environmental departments in these nonenvironmental bureaucracies perform less than could be expected from a fully fledged environmental organization. The environment division of the secretariat of the International Maritime Organization, for example, has been shown as being strongly influenced by the overall technocratic approach of this organization that favors the interests of unhindered maritime transport and the shipping industry (Campe 2009). Equally, the environmental activities of the UN Food and Agriculture Organization might be overly influenced by the production-oriented mission of this large bureaucracy. While it seems unlikely that a new UN environment agency would easily be transferred core functions and bureaucratic units of non-environmental organizations, a "slippery slope" in this direction might well be created over time.

14 Esty $(1996,111)$ for instance has suggested that UN specialized agencies such as the World Meteorological Organization may be merged into a new global environmental agency. 


\subsection{Hierarchization through creation of a new agency}

The fourth and most far-reaching option is that of a hierarchical intergovernmental organization on environmental issues that would be equipped with majority decision making as well as with enforcement powers - such as trade sanctions-vis-à-vis states that fail to comply with international agreements. Proposals in this direction are usually the domain of environmental activists who lament the relatively slow pace of environmental negotiations and treaty implementation. Yet also some governments and intergovernmental processes have at times shown a certain openness for majority decision-making and stronger enforcement powers. For example, the Hague Declaration of 1989 seemed to have veered in the direction of an environmental agency with sanctioning powers, and at the end of the 1980s, New Zealand had suggested establishing an "environment protection council", whose decisions would be binding. ${ }^{15}$ Yet support for hierarchical models remains scarce. The only example for a quasi-supranational body at the global level is the UN Security Council, which enjoys far-reaching powers under Chap. VII of the UN Charter. However, while the prospective benefits of an "environmental security council" remain a part of the overall discourse, such an organization does not appear to be a realistic option in the next decades - and it is open to doubt whether it would be desirable at all.

The creation of such an organization would involve major organizational change as existing organizations and their bureaucracies would be incorporated and loose their independence. It would also demand the most far-reaching institutional change, as the formation would require major alterations in the current institutional system. Naturally, the establishment of a hierarchical intergovernmental organization for the environment will improve environmental policy integration. Yet such proposals are largely unrealistic, might come with major problems in other areas-especially when it comes to North-South relations-and are for these reasons decreasing in relevance in both the academic and policy communities.

\section{Conclusion}

The debate on how to improve global environmental governance has proceeded in surges and continues to do so, as new initiatives unfold and older ideas resurface. Currently, reforming the UN system is mentioned as a top priority for UN Secretary General Ban $\mathrm{Ki}-$ Moon (as it has been for his predecessors). ${ }^{16}$ Recent UN proposals to strengthen the environmental dimension of sustainable development include the recommendations of the High-Level Panel on System Wide Coherence in their report Delivering as One and the Inter-Linkages Initiative by the UN University, which advocates better harmonization and coordination between multilateral environmental agreements. These proposals remain close to the current system and offer potential for reform in the short term. Also, clustering holds some promise for improvements. However, although parts of the literature present clustering of institutions and bureaucracies as an option that renders a new world environment organization redundant, clustering is more likely to be part of a larger solution toward more effective global environmental governance and can be best understood as a transitionary tool for pursuing this reform in a bottom-up process.

\footnotetext{
15 United Nations General Assembly, General Debate Settlement at the 44th Session, October 2, 1989, Statement of the Right Honourable Geoffrey Palmer, Prime Minister of New Zealand. See also Palmer (1992, at 278ff).

16 See: Secretary-General's press conference, New York, September 18, 2007, available online at http://www.un.org/apps/sg/sgstats.asp?nid=2739.
} 
Table 3 Summary of key findings

\begin{tabular}{|c|c|c|c|c|}
\hline & Clustering & $\begin{array}{l}\text { UNEP upgrade to } \\
\text { UNEO }\end{array}$ & Streamlining & Hierarchization \\
\hline $\begin{array}{l}\text { Will reform proposal } \\
\text { improve the } \\
\text { integration of different } \\
\text { intergovernmental } \\
\text { environmental } \\
\text { institutions? }\end{array}$ & $\begin{array}{l}\text { Yes, yet } \\
\text { not } \\
\text { formally }\end{array}$ & $\begin{array}{l}\text { Yes, yet not formally, } \\
\text { but with stronger } \\
\text { coordinating } \\
\text { bureaucracy at the } \\
\text { center }\end{array}$ & $\begin{array}{l}\text { Yes, through } \\
\text { institutional } \\
\text { integration in } \\
\text { larger organization }\end{array}$ & $\begin{array}{l}\text { Yes, through } \\
\text { institutional } \\
\text { integration in } \\
\text { larger organization } \\
\text { with enforcement } \\
\text { mechanism }\end{array}$ \\
\hline $\begin{array}{l}\text { Will reform proposal } \\
\text { improve the cognitive, } \\
\text { normative, and } \\
\text { executive influence of } \\
\text { the UN system by } \\
\text { better integrating } \\
\text { existing actors with } \\
\text { an environmental } \\
\text { mandate? }\end{array}$ & No & $\begin{array}{l}\text { No with regard to } \\
\text { integration; but a } \\
\text { stronger } \\
\text { bureaucracy at the } \\
\text { center will have } \\
\text { more cognitive, } \\
\text { normative, and } \\
\text { executive influence } \\
\text { in global } \\
\text { environmental } \\
\text { governance }\end{array}$ & $\begin{array}{l}\text { Yes, mainly through } \\
\text { integration of } \\
\text { environmental } \\
\text { treaty secretariats } \\
\text { (and possibly also } \\
\text { parts of other } \\
\text { organizations) }\end{array}$ & $\begin{array}{l}\text { Yes, mainly through } \\
\text { integration of } \\
\text { environmental } \\
\text { treaty secretariats } \\
\text { (and possibly also } \\
\text { parts of other } \\
\text { organizations) }\end{array}$ \\
\hline $\begin{array}{l}\text { Will reform proposal } \\
\text { improve the } \\
\text { integration of } \\
\text { intergovernmental } \\
\text { environmental } \\
\text { institutions with non- } \\
\text { environmental } \\
\text { institutions? }\end{array}$ & $\begin{array}{l}\text { Probably } \\
\text { not }\end{array}$ & $\begin{array}{l}\text { Yes, yet not formally, } \\
\text { but a stronger } \\
\text { environmental } \\
\text { bureaucracy } \\
\text { improves } \\
\text { coordinating and } \\
\text { policy-development } \\
\text { role vis-à-vis non- } \\
\text { environmental } \\
\text { institutions }\end{array}$ & $\begin{array}{l}\text { Probably not more } \\
\text { than in the case of } \\
\text { upgrading }\end{array}$ & $\begin{array}{l}\text { Probably not more } \\
\text { than in the case of } \\
\text { upgrading }\end{array}$ \\
\hline $\begin{array}{l}\text { Will reform proposal } \\
\text { improve the cognitive, } \\
\text { normative, and } \\
\text { executive influence of } \\
\text { the UN system by } \\
\text { better integrating } \\
\text { environmental actors } \\
\text { and non-environmental } \\
\text { actors? }\end{array}$ & $\begin{array}{l}\text { Probably } \\
\text { not }\end{array}$ & $\begin{array}{l}\text { Yes, yet not formally, } \\
\text { but a stronger } \\
\text { environmental } \\
\text { bureaucracy } \\
\text { improves } \\
\text { coordinating and } \\
\text { policy-development } \\
\text { role vis-à-vis non- } \\
\text { environmental } \\
\text { organizations and } \\
\text { their bureaucracies }\end{array}$ & $\begin{array}{l}\text { Yes, if functions } \\
\text { from non- } \\
\text { environmental } \\
\text { organizations are } \\
\text { being transferred to } \\
\text { the new } \\
\text { environmental } \\
\text { agency }\end{array}$ & $\begin{array}{l}\text { Yes, if functions } \\
\text { from non- } \\
\text { environmental } \\
\text { organizations are } \\
\text { being transferred to } \\
\text { the new } \\
\text { environmental } \\
\text { agency }\end{array}$ \\
\hline
\end{tabular}

In the longer term, upgrading UNEP and (later) streamlining it with other institutions and bureaucracies appears as a both necessary and feasible option for reforming global environmental governance, while at the same time offering potential for increasing environmental policy integration at the global level (see Table 3 for a summary of our argument). The highest promise of both upgrading and streamlining lies in increased internal environmental policy integration within the environmental realm. Integration beyond the environmental sphere, most significantly by integrating environment and development, is likely to be improved too, yet probably to a lesser degree.

Pursuing the upgrading and streamlining approach will bring organizational and institutional change to the current system, and realization of either option thus requires substantial support from all major governments. It is thus unlikely that either of these options could be realized in the short term. 
Essential to the success of any new organization is the support from developing countries. This is substantiated by the most recent phase in the debate on improving global environmental governance. Brazil has instigated a new round of discussion, by giving the proposal for a combined organization for environment and development new impetus. It has recently started a new endeavor from within diplomatic circuits, to gather support for such an organization. An organization combining environment and development is likely to receive more support from developing countries, as developing countries often fear a strong environmental organization would be detrimental to developmental issues. Incorporating these issues within a strong combined organization would prevent development from a decline in consideration. However, merging environmental policies with development policies in one institutional and organizational setting brings with it also certain dangers, including the possibility that environmental concerns-which are of core interest today also in the developing world—are effectively marginalized in the process (Biermann 2005, 132-135).

An alternative option - and probably the preferable one-would be to establish a strong environmental organization while altering UNDP's status simultaneously. This way, both environment and development would have a strong voice, without compromising one or the other. Developing countries might be easier inclined to support a new environmental organization, when it involves improved status for UNDP as well.

Acknowledgments This research has been financially supported by the project "Environmental Policy Integration and Multi-level Governance" (EPIGOV), a Co-ordinated Action under the European Union 6th Research Framework Programme CITIZENS-2004-4.2.2 (Governance for Sustainable Development). We are grateful to valuable comments by the editors and the anonymous reviewers of this special issue of INEA, as well as to Aizo Lijcklama for his research assistance.

Open Access This article is distributed under the terms of the Creative Commons Attribution Noncommercial License which permits any noncommercial use, distribution, and reproduction in any medium, provided the original author(s) and source are credited.

\section{References}

Andresen, S. (2007). The effectiveness of UN environmental institutions. International Environmental Agreements, 7, 317-336.

Bachelot-Narquin (2004). Intervention de la ministre de l'écologie et de la développement durable, speech delivered at the conference 'Gouvernement internationale de l'énvironnement', IDDRI, Paris, 15-16 March, retrieved from http://www.iddri.org.

Bauer, S. (2009). The secretariat of the United Nations Environment Programme: Tangled up in blue. In F. Biermann \& B. Siebenhüner (Eds.), Managers of global change. The influence of international environmental bureaucracies (pp. 169-202). Cambridge, MA: MIT Press.

Bauer, S., \& Biermann, F. (2005). The debate on a world environment organization: An introduction. In F. Biermann \& S. Bauer (Eds.), A world environment organization: Solution or threat for effective international environmental governance? (pp. 1-26). Aldershot, UK: Ashgate.

Berruga, E., \& Maurer, P. (2007). The informal consultative process on the institutional framework for the UN's environmental activities: Co-chairs summary. In L. Swart \& E. Perry (Eds.), Global environmental governance: Perspectives on the current debate (pp. 16-25). New York: Center for UN Reform Education.

Biermann, F. (2000). The case for a world environment organization. Environment, 42(9), 22-31.

Biermann, F. (2001). The emerging debate on a world environment organization: A commentary. Global Environmental Politics, 1(1), 45-55.

Biermann, F. (2002). Strengthening green global governance in a disparate world society: Would a world environment organization benefit the South? International Environmental Agreements: Politics, Law and Economics, 2, 297-315. 
Biermann, F. (2005). The rationale for a world environment organization. In F. Biermann \& S. Bauer (Eds.), A world environment organization: Solution or threat for effective international environmental governance? (pp. 117-144). Aldershot, UK: Ashgate.

Biermann, F., \& Bauer, S. (Eds.). (2005). A world environment organization: Solution or threat for effective international environmental governance?. Aldershot, UK: Ashgate.

Biermann, F., \& Pattberg, P. (2008). Global environmental governance. Taking stock, moving forward. Annual Review of Environment and Resources, 33, 277-294.

Biermann, F., \& Siebenhüner, B. (Eds.). (2009). Managers of global change. The influence of international environmental bureaucracies. Cambridge, MA: MIT Press.

Biermann, F., Pattberg, P., van Asselt H. \& Zelli F. (2009a). The fragmentation of global governance architectures. A framework for analysis. Global Environmental Politics 9(4) (in press).

Biermann, F., Siebenhüner, B., Bauer, S., Busch, P.-O., Campe, S., Dingwerth, K., et al. (2009b). Studying the influence of international bureaucracies: A conceptual framework. In F. Biermann \& B. Siebenhüner (Eds.), Managers of global change. The influence of international environmental bureaucracies (pp. 37-74). Cambridge, MA: MIT Press.

Campe, S. (2009). The secretariat of the International Maritime Organization: A tanker for tankers. In F. Biermann \& B. Siebenhüner (Eds.), Managers of global change. The influence of international environmental bureaucracies (pp. 143-168). Cambridge, MA: MIT Press.

Charnovitz, S. (1993). The environment vs. trade rules: Defogging the debate. Environmental Law, 23, $475-517$.

Charnovitz, S. (2005). Toward a world environment organization: Reflections upon a vital debate. In F. Biermann \& S. Bauer (Eds.), A world environment organization: Solution or threat for effective international environmental governance? (pp. 87-144). Aldershot, UK: Ashgate.

Co-Chairs Options Paper. (2007). Informal consultative process on the institutional framework for the United Nations' environmental activities. New York. Retrieved from http://www.un.org/ga/ president/61/follow-up/environment/EG-OptionsPaper.PDF.

Desai, B. (2000). Revitalizing international environmental institutions: The UN Task Force Report and beyond. Indian Journal of International Law, 40(3), 455-504.

Dodds, F., Gardiner, R., Hales, D., Hemmati, M., \& Lawrence, G. (2002). Post Johannesburg. The future of the UN Commission on Sustainable Development (WHAT Governance Programme, retrieved from http://www.earthsummit2002.org/es/issues/Governance/csdfuture.pdf).

Elliott, L. (2005). The United Nations' record on environmental governance: An assessment. In F. Biermann \& S. Bauer (Eds.), A world environment organization: Solution or threat for effective international environmental governance? (pp. 27-56). Aldershot, UK: Ashgate.

Esty, D. C. (1994). The case for a global environmental organization. In P. B. Kenen (Ed.), Managing the world economy: Fifty years after Bretton Woods (pp. 287-309). Washington, D.C.: Institute for International Economics.

Esty, D. C. (1996). Stepping up to the global environmental challenge. Fordham Environmental Law Journal, 8(1), 103-113.

Fitzmaurice, M. (2001). International protection of the environment. Recueil des Cours, 293, 9-488.

Haas, P. M. (2004). Science policy for multilateral environmental governance. In N. Kanie \& P. M. Haas (Eds.), Emerging forces in environmental governance. Tokyo: United Nations University Press.

Haas, P. M. (2005). Addressing the global governance deficit. In A. Rechkemmer (Ed.), UNEO-Towards an international environment organization (pp. 47-61). Baden-Baden: Nomos.

Hertin, J., \& Berkhout, F. (2003). Analysing institutional strategies for environmental policy integration: The case of EU enterprise policy. Journal of Environmental Policy \& Planning, 5(1), 39-56.

Hierlmeier, J. (2002). UNEP: Retrospect and prospect-Options for reforming the global environmental governance regime. Georgetown International Law Review, 14(2), 767-805.

IHDP, International Human Dimensions Programme on Global Environmental Change. (1999). Institutional dimensions of global environmental change: Science plan. IHDP Report 9. Bonn: IHDP.

Ivanova, M. (2007a). Moving forward by looking back: Learning from UNEP's history. In L. Swart \& E. Perry (Eds.), Global environmental governance: Perspectives on the current debate (pp. 26-47). New York: Center for UN Reform Education.

Ivanova, M. (2007b). International environmental governance reform: Options and implications. London: Royal Institute of International Affairs, retrieved from http://www.chathamhouse.org.uk/files/ 9798_260707ieg2.pdf.

Kanie, N., \& Haas, P. M. (Eds.). (2004). Emerging forces in environmental governance. Tokyo: United Nations University Press.

Kimball, L. A. (2002). The debate over a world/global environment organization: A first step toward improved international institutional arrangements for environment and development. In D. Brack \& 
J. Hyvarinen (Eds.), Global environmental institutions. Perspectives on reform (pp. 19-31). London: Royal Institute of International Affairs.

Krasner, S. D. (1983). Structural causes and regime consequences: Regimes as intervening variables. In S. D. Krasner (Ed.), International regimes (pp. 1-21). Ithaca: Cornell University Press.

Lafferty, W. M., \& Hovden, E. (2003). Environmental policy integration: Towards an analytical framework. Environmental Politics, 12(3), 1-22.

Lodefalk, M., \& Whalley, J. (2002). Reviewing proposals for a world environmental organisation. The World Economy, 25(5), 601-617.

McGoldrick, D. (1996). Sustainable development and human rights: An integrated approach. International and Comparative Law Quarterly, 45(4), 796-818.

Najam, A. (2005a). Developing countries and environmental governance: From contestation to participation and engagement. International Environmental Agreements: Politics, Law and Economics, 5, 303-321.

Najam, A. (2005b). Neither necessary, nor sufficient: Why organizational tinkering will not improve environmental governance. In F. Biermann \& S. Bauer (Eds.), A world environment organization: Solution or threat for effective international environmental governance? (pp. 235-256). Aldershot, UK: Ashgate.

Najam, A., Papa, M. \& Taiyab, N. (2007). Global environmental governance: A reform agenda. Winnipeg, Canada: International Institute for Sustainable Development.

Nilsson, M. (2005). Learning, frames and environmental policy integration: the case of Swedish energy policy. Environment and Planning C: Government and Policy, 23, 207-226.

Nilsson, M., \& Eckerberg, K. (Eds.). (2007). Environmental policy integration in practice. Shaping institutions for learning. London: Earthscan.

Nilsson, M., Pallemaerts, M., \& von Homeyer, I. (2009). International regimes and environmental policy integration: Introducing the special issue. International Environmental Agreements: Politics, Law and Economics (this issue).

Oberthür, S. (2002). Clustering of multilateral environmental agreements: Potentials and limitations. International Environmental Agreements: Politics, Law and Economics, 2(4), 317-340.

Oberthür, S. (2009). Enhancing environmental policy integration among international institutions. International Environmental Agreements: Politics, Law and Economics (this issue).

Oberthür, S., \& Gehring, T. (2005). Reforming international environmental governance: An institutional perspective on proposals for a world environment organization. In F. Biermann \& S. Bauer (Eds.), A World Environment Organization: Solution or threat for effective international environmental governance? (pp. 205-234). Aldershot, UK: Ashgate.

Palmer, G. (1992). New ways to make international environmental law. American Journal of International Law, 86, 259-283.

Persson, A. (2009). Environmental policy integration and bilateral development assistance: challenges and opportunities with an evolving governance framework. International Environmental Agreements: Politics, Law and Economics (this issue).

Rechkemmer, A. (Ed.). (2005). UNEO-Towards an international environment organization. Baden-Baden: Nomos.

Runge, C. F. (1994). Freer trade, protected environment. New York: Council on Foreign Relations.

Simmons, B. A., \& Martin, L. L. (2002). International organizations and institutions. In W. Carlsnaes, T. Risse, \& B. A. Simmons (Eds.), Handbook of international relations (pp. 192-211). London: Sage.

Speth, J. G. (2004). Red sky at morning: America and the crisis of the global environment. New Haven: Yale University Press.

Tarasofsky, R. (2002). International environmental governance: Strengthening UNEP. UNU Working Paper, retrieved from http://www.unu.edu/inter-linkages/docs/IEG/Tarasofsky.pdf.

United Nations General Assembly. (1972). Resolution 2997 (XXVII): Institutional and financial arrangements for international environmental cooperation, 15 Dec 1972.

United Nations Office of Internal Oversight Services. (1997). Report of the Office of Internal Oversight Services on the review of the United Nations Environment Programme and the administrative practices of its secretariat, including the United Nations Office at Nairobi. (UN Doc. A/51/810).

United Nations Secretary-General. (1998). Environment and human settlements. Report of the SecretaryGeneral to the 53. Session of the United Nations General Assembly. (UN Doc. A/53/463).

Von Homeyer, I., Goria A., Nilsson M., \& Pallemaerts M. (Eds.) (2009) The prospects and practice of environmental policy integration-A multi-level governance perspective. Cheltenham: Edward Elgar.

Von Moltke, K. (2005). Clustering international environmental agreements as an alternative to a world environment organization. In F. Biermann \& S. Bauer (Eds.), A world environment organization: Solution or threat for effective international environmental governance? (pp. 175-204). Aldershot, UK: Ashgate. 
Whalley, J., \& Zissimos, B. (2002). Making environmental deals: The economic case for a world environment organization. In D. C. Esty \& M. Ivanova (Eds.), Global environmental governance: Options and opportunities (pp. 163-180). New Haven: Yale School of Forestry and Environmental Studies.

World Commission on Environment and Development. (1987). Our common future. New York: Oxford University Press.

Young, O. R., King, L. A., \& Schroeder, H. (2008). Institutions and environmental change: Principal findings, applications, and research frontiers. Cambridge, MA: MIT Press. 